\title{
IDENTIFYING THE FACTORS AFFECTING PUBLIC ADMINISTRATION STUDENTS' COURSE CONTENT EVALUATION
}

\author{
Burak HERGÜNER \\ İzmir Demokrasi Üniversitesi, Türkiye \\ burak.herguner@idu.edu.tr \\ https://orcid.org/ 0000-0002-6240-5463
}

\begin{abstract}
This study aims at exploring the elements affecting public administration students' course content evaluation results. Empirical data were gathered from 171 public administration students from three different universities chosen by cluster sampling method. The questionnaire survey was used to collect the data. Exploratory Factor Analysis, Cronbach's alpha test were used to analyze the data and the relationships were examined through Structural Equation Modeling. The current study describes a model in a reliable and valid way. In the study, exploratory factor analysis (EFA) and confirmatory factor analysis (CFA) were both applied to identify clusters of variables to minimize the potential common method variance (CMV) effect. The study proved that there is a significant difference between public and foundation universities in terms of public administration students' course content evaluation. Besides, student satisfaction and perceived significance both affect students' evaluation of course content.
\end{abstract}

Keywords: Course content, Student Satisfaction, Public Administration Students, Public Affairs

\section{KAMU YÖNETIMI ÖĞRENCILLERININ DERS İÇERIKK DEĞERLENDİRMELERINII ETKILEYEN FAKTÖRLER}

\begin{abstract}
ÖZ
$\mathrm{Bu}$ çalışma, kamu yönetimi öğrencilerinin aldıkları dersin ders içeriğine yönelik değerlendirmelerini etkileyen faktörleri ortaya koymaktadır. Çalışmadaki empirik veriler küme örneklem yöntemiyle belirlenmiş üç farklı üniversitede eğitim görmekte olan toplam 171 kamu yönetimi bölümü öğrencisinden anket yoluyla toplanmıştır. Keşfedici faktör analizi, Cronbach's alfa testi verilerin analizinde kullanılmış ve ayrıca değişkenler arası ilişkiler yapısal eşitlik modellemesi yoluyla sınanmıştır. Bu sayede geçerli ve güvenilir bir model ortaya konmuştur. Çalışmada keşfedici faktör analizi ve doğrulayıcı faktör analizi yöntemleri birarada kullanılarak muhtemel ortak yöntem varyans (OYV) problemi en alt seviyeye indirilmiştir. Çalışmada, kamu ve vakıf üniversitelerinde eğitim gören kamu yönetimi öğrencilerinin ders içeriği değerlendirmeleri arasında anlamlı bir fark bulunmuştur. Ayrıca, öğrencilerin tatmini ve algılanan önem de öğrencilerin ders içerik değerlendirmelerini etkilemektedir.
\end{abstract}

\section{Anahtar kelimeler: Ders İ̧̧eriği, Öğrenci Tatmini, Kamu Yönetimi Öğrencileri, Kamu Yönetimi}

\section{INTRODUCTION}

The main objective of public administration/affairs programs is to equip students with the essential knowledge, skills, and habits of mind required to become competent public managers. However, funding for higher education is tied to the quality of outcomes, and program competition increases. In this competitive environment, students' success is crucial for any higher education institution to sustain itself. Thus, it becomes necessary for public administration/affairs departments to have knowledge of student satisfaction, students' perception about offered courses and their opinions about the course content (Atchley et al., 2013; Bright and Graham, 2016).

Accordingly, course content is one of the primary tools for public administration/affairs departments to achieve their policy objectives. Put another way, variations in value emphasis across institutions have implications for course content (Aoki, 2015; Brans and Coenen, 2016; Ebdon, 1999; Rissi and Gelmon, 2014; West, 1994). Therefore, public administration/affairs departments usually benefit from student 
assessments to refine program components and course content to achieve their objectives (Lopez-Littleton and Blessett, 2015).

On the grounds mentioned above, the following is the main research question this study seeks to answer: What factors affect the public administration students' evaluation of course content?

In the study, the research methods course was chosen to be analyzed. Because, even if not all the public administrators need to be a researcher, they will all make decisions in public offices. Surely, to make sound decisions, they should be capable of assessing the quality and applicability of research introduced to them. In the absence of relevant research, they should know what to ask for from others. Many public administration scholars know this and the public administration/affairs curricula reflect priority placed on research (Rubaii, 2019).

This study first explores the relevant literature and proposes a research model. Then, it gives details about the research design. Afterward, it discusses the findings and finally comes to a conclusion. The findings of this study are expected to be helpful for public administration/affairs programs.

\section{THEORETICAL BACKGROUND}

\section{Course content evaluation and student satisfaction}

Student satisfaction is a short-term attitude derived from an assessment of the experience with the provided educational service (Elliot \& Healy, 2001). Students are satisfied when they feel pleased with their experience with different mechanisms of education, and as a result, their satisfaction becomes crucial for efficient learning (Alves \& Raposo, 2009; Horvat et al., 2012; Moore \& Kearsley, 1996). The more students are satisfied, the more likely they do well in the course (Garg, 2018; Keller, 1983; Pike, 1993).

In the higher education literature, students' and teachers' thinking styles (Betoret, 2007), course utility (Colorado \& Eberle, 2010), clarity of course design (Hergüner, 2019; Swan et al., 2000), clarity of course objectives (Hergüner, 2019; Powell, 2007) are among the most critical factors linked with student satisfaction.

A low level of course content evaluation implies either that the content did not make a difference, or it was not adequately described so that differences could be noticed (Schram, 1996). Thus, to meet a student's expectations, lecturers must know their students and understand their expectations. That is, course evaluation is more likely to be determined by how well lecturer performance fulfills innate needs, wants, or desires, rather than how performance compares with presumed predictions. In the literature, Hearn (1985); Irani (1998); Moore (1989); Shea, Pickett, and Pelz (2003); Swan (2001); Young \& Norgard (2006) underlined the correlation between course design/content and students' satisfaction. Likewise, Hau-Siu Chow (1995) maintains that Asian cultures place a high value on the orderliness of the course in education.

\section{Course content evaluation and perceived significance}

Today, the instructors are no longer the primary source of students' knowledge. Instead, they are considered to be the manager of the students' knowledge resources (Romiszowski, 2004). Hence, they must understand the diversity of learners and then determine appropriate assessment strategies and measurement practices in their course (Banerjee \& Brinckerhoff, 2002). Han et al., (2018) documented the role of perceived significance in higher education. Before taking any course, students form expectations of the said course. Then, the course experience induces a perceived significance level that is influenced by the difference between actual significance perceptions and expectations.

Keeping in mind the literature, the current study examined the links between course content (CC), perceived significance (PS) and student satisfaction (SS). Besides, gender was included in the study because it has been previously shown to have an impact on the way of thinking of students (Finnie, Mueller, \& Childs, 2010; Holtbrügge \& Engelhard, 2016). School type was also included as a variable since foundation universities recruit instructors who are arguably more liberal in their world view (Özdemirci, Özcan, \& İldaş, 2014). 
Thus, the hypotheses to be tested are as follows:

H1: The perceived significance of public administration/affairs students positively affects their evaluation of course content.

H2: Public administration/affairs students' satisfaction positively affects their evaluation of course content.

H3: There is a positive correlation between perceived significance and student satisfaction.

H4: There is a significant difference between the evaluation of public administration/affairs students enrolled in a foundation university and public university.

H5: There is a significant difference between the course content evaluation of male and female public administration/affairs students.

\section{METHODOLOGY}

\section{Questionnaire}

A 17-item scale excluding the demographic questions was developed based on the literature. For each questionnaire item, there were seven categories of response from $1=$ strongly disagree to $7=$ strongly agree. Gender variable was coded as " 0 " for males and " 1 " for females, whereas school type was coded as 0 if the participant is from a public university, and 1 if $\mathrm{s} / \mathrm{he}$ is from a foundation university. The data were later analyzed using the SPSS software version 20.0 and AMOS version 25.0.

The scale was administered to the public administration students to measure the CC, PS, and self-reported SS about research methods course. Five items were adapted from the study of Arbaugh (2000), Chamillard et al., (2002), Han et al. (2018) and Simpson \& Du (2004) to measure the student satisfaction for research methods. Likewise, seven items were adapted from the study of Arbaugh (2000) to measure perceived significance. Finally, for the course content evaluation, five items were adapted and modified from the work of Tallent-Runnels et al., (2005) and Harris et al., (2009).

\section{Participants}

The research was conducted at one foundation and two public universities located in three different regions of Turkey-Blacksea region, Central Anatolia region and Aegean region. The said three universities were chosen by cluster sampling method. Cluster sampling is advantageous when a sampling frame of elements is not available, as often is the case for large populations spread out across a wide geographic area. A cluster is a naturally occurring, mixed aggregate of elements of the population, with each element appearing in one cluster. Schools, for example, could serve for clusters for sampling students (Schutt, 2004: p.144).

The data were collected at the end of the 2018-19 Spring term from the public administration students who took a research methods course in the said term. A seven-point Likert scale survey was carried out during classes in the presence of the course instructor in May 2019. Student participation in the survey was voluntary, and all the available students filled out the questionnaire.

One hundred seventy-one questionnaires were collected over two weeks. One participant was excluded from the analysis because of missing data, and one hundred sixty-six questionnaires were confirmed as valid by the logic question (i.e., the same question asked in a different way), including eighty-eight female respondents $(53 \%)$ and seventy-eight male respondents $(43 \%)$. One hundred forty-three undergraduate $(86.2 \%)$ and twenty-three graduate students $(13.8 \%)$ participated in the research.

\section{Common method variance}

Common method variance (CMV) is the systematic error variance that is shared among variables which are measured with the same method (Jakobsen and Jensen, 2015; Tehseen, Ramayah and Sajilan, 2017).

In this study, initially, exploratory factor analysis (EFA) was applied to identify clusters of variables to minimize the potential CMV effect. Later, a reliability test was made to assess internal consistency amongst the items loaded on the extracted factors as suggested by Podsakoff et al. (2003); Ugaddan and Park (2017). The sampling adequacy and significance were tested through Kaiser-Meyer-Olkin (KMO) and Bartlett's test 
before the exploratory factor analysis (EFA). Then, the reliability analysis was performed using the internal consistency estimated by Cronbach's alpha coefficient.

KMO and Bartlett's tests measure the suitability of the sample data for factor analysis. KMO test evaluates sampling adequacy to understand whether the distribution of values is sufficient for conducting factor analysis. The EFA is used to explore the possible underlying factor structure of a set of observed variables without imposing a preconceived structure on the outcome, whereas confirmatory factor analysis (CFA) is a statistical technique used to verify the factor structure of a set of observed variables. Therefore, CFA requires specification of a model a priori, the number of factors and items load on each factor (Shur 2006).

In the study, KMO and Bartlett's tests were performed and gave satisfactory results $(\mathrm{KMO}=0.887$ and Bartlett $<0.001$ ). The KMO statistic varies between 0 and 1 , and the value should be higher than the acceptable threshold of 0.5 to proceed with EFA (Chan et al., 2010; Fox \& Skitmore, 2007). However, for Pallant (2001); Tabachnick \& Fidell (2007), the minimum KMO value should be 0,6. Besides, KMO values over 0.8 indicate that included variables are fittingly predicted without error by other variables. The Bartlett's test for sphericity is performed to highlight the presence of correlations among the variables, and it should be below 0.05 significance level (Durmuş et al. 2013; George \& Mallery 2016). Therefore, the abovementioned results prove that the sample data are suitable for the factor analysis.

Later, the sample data of 166 responses were analyzed using a principal component factor analysis together with varimax-rotation with Kaiser normalization method. Varimax rotation was applied as the objective was also to determine those factors which are uncorrelated with each other. Item reduction procedure was administered based on the criteria of eliminating items with factor loadings less than 0.40 on all factors. Accordingly, items with loadings of 0.40 or greater on one factor were retained as components of that factor. The exploratory factor analysis resulted in a total of three factors. All three factors had eigenvalues greater than 1, explaining 48.169 percent of the total variance. The said level is greater than Kline's (1994) suggested a minimum level of 40 percent.

Table 1 indicates three constructs-PS, CC, and SS - with Cronbach's alpha values and corresponding items with standardized factor loadings. All the items associated with their particular constructs were found to be statistically significant $(\mathrm{p}<.001)$. In this research, Cronbach's alpha values were computed for the reliability testing of the study instrument. An acceptable alpha level for a scale is regarded to be 0.7 or higher (Buckley, 2013). However, in the literature, numerous researchers are using 0.5 as the threshold (Tan, 2009). Durmuş et al., (2013) consider the minimum acceptable alpha level to be 0.6. Besides, Özdamar (1999) and Yaşar (2014) maintain that an alpha level of 0.4 or higher can be acceptable as alpha scores are known to be affected by the number of items in a scale and low numbers of items can artificially deflate the alpha values. Furthermore, for Özdamar (1999) and Yaşar (2014), an alpha level between 0.80 and 1.00 denotes high reliability. The alpha levels of three constructs in this study are all above 0.8 . 
Table 1. Exploratory Factor Analysis Results

\begin{tabular}{|c|c|c|c|}
\hline \multirow{3}{*}{$\begin{array}{l}\text { Constructs } \\
\text { Perceived } \\
\text { significance / } \\
\text { usefulness ( } \alpha \\
=.888)\end{array}$} & \multicolumn{2}{|c|}{ Survey Items } & \multirow{2}{*}{$\begin{array}{l}\text { Factor } \\
\text { loadings } \\
.659\end{array}$} \\
\hline & Q1 & I am interested in learning research methods. & \\
\hline & Q2 & $\begin{array}{l}\text { I find it interesting to research with the knowledge I have from } \\
\text { the research methods course. }\end{array}$ & .691 \\
\hline & Q5 & I believe that exploratory thinking is an integral part of my life. & .721 \\
\hline & Q6 & $\begin{array}{l}\text { I believe that the abilities acquired in the research methods } \\
\text { course will help me to reach my future career goals. }\end{array}$ & .723 \\
\hline & Q7 & $\begin{array}{l}\text { I would participate in the research methods course, even if the } \\
\text { absenteeism were allowed. }\end{array}$ & .471 \\
\hline & Q8 & I can use research methods in different phases of my life. & .809 \\
\hline & Q9 & $\begin{array}{l}\text { The research methods course is a fundamental curriculum } \\
\text { requirement. }\end{array}$ & .666 \\
\hline \multirow{5}{*}{$\begin{array}{l}\text { Course } \\
\text { Content } \\
\text { Evaluation } \\
(\alpha=.859)\end{array}$} & Q3 & The research methods course was enjoyable. & .687 \\
\hline & Q4 & $\begin{array}{l}\text { The instructor stimulated student learning and encouraged } \\
\text { comments. }\end{array}$ & .560 \\
\hline & Q14 & The course subjects were in line with the course objectives. & .680 \\
\hline & Q15 & Course materials were relevant and up to date. & .744 \\
\hline & Q16 & $\begin{array}{l}\text { The instructor demonstrated knowledge of the subject and } \\
\text { welcomed questions. }\end{array}$ & .803 \\
\hline \multirow{5}{*}{$\begin{array}{l}\text { Student } \\
\text { Satisfaction } \\
(\alpha=.848)\end{array}$} & Q10 & I believe that I will succeed in the research methods course. & .719 \\
\hline & Q11 & $\begin{array}{l}\text { I am successful in the research methods course, just like other } \\
\text { courses. }\end{array}$ & .781 \\
\hline & Q12 & $\begin{array}{l}\text { My motivation to learn has increased because of taking this } \\
\text { course. }\end{array}$ & .795 \\
\hline & Q13 & $\begin{array}{l}\text { This course improved my ability to deal with problems that } \\
\text { don't have an approved solution. }\end{array}$ & .451 \\
\hline & Q17 & $\begin{array}{l}\text { I can easily complete my dissertation as I learnt research } \\
\text { methods. }\end{array}$ & .715 \\
\hline
\end{tabular}

Note: Cronbach's alpha in parentheses 


\section{RESULTS \\ Descriptive statistics}

Table 2 shows the minimum and maximum score, the mean and the standard deviation in addition to the correlated coefficient information of the variables. As seen in the Table, both of the tested independent variables - PS and SS - were found to have a statistically significant correlation to course content evaluation along with school type. Accordingly, the hypothesis test results are as follows: H1 (Accepted $-\mathrm{r}=0.717$ and $p$ $<0.01$ ); H2 (Accepted- $r=0.660$ and $p<0.01$ ); H3 (Accepted- $r=-0.591$ and $p<0.01$ ); H4 (Accepted- $r=$ 0.297 and $p<0.01$ ); H5 (Rejected). Therefore, gender was not included as an exogenous variable in the measurement model.

Table 2: Descriptive Statistics and Correlation

\begin{tabular}{|l|l|l|l|l|l|l|l|l|l|l|}
\hline & & $\mathrm{N}$ & Min. & Max. & Mean & SD & 1 & 2 & 3 & 4 \\
\hline 1 & $\begin{array}{l}\text { Gender (female= 0; } \\
\text { male=1) }\end{array}$ & 166 & 0,00 & 1,00 & 0,47 & 0,50 & & & & \\
\hline 2 & $\begin{array}{l}\text { School Type (Public=0; } \\
\text { Foundation=1) }\end{array}$ & 166 & 0,00 & 1,00 & 0,49 & 0,50 &,- 134 & & & \\
\hline 3 & CC & 166 & 5,00 & 35,00 & 28,60 & 5,65 &, 025 &,$- 297 * *$ & \\
\hline 4 & PS & 166 & 9,00 & 49,00 & 38,14 & 7,83 &, 139 &,- 123 &, $717^{* *}$ & \\
\hline 5 & SS & 166 & 6,00 & 35,00 & 27,02 & 5,53 &, 006 &,- 121 &, $660^{* *}$ &, $591 * *$ \\
\hline
\end{tabular}

\section{The measurement model}

CFA is a multivariate technique which is used to confirm a hypothesized relationship structure between the items and the factors. It is also known as the measurement model in structural equation modeling (SEM) (Nu'man, 2012), which has indeed been an analytic approach with growing popularity (Liem, 2019).

Table 3 indicates the values of standardized regression weights and squared multiple correlations of 17 items in the model. As seen in the Table, the values were between 0.524 and 0,859. So, they were all above the recommended threshold of 0.5 suggested by Hair et al. (2014). 
Table 3. Confirmatory Factor Analysis Results

\begin{tabular}{|c|c|c|c|}
\hline Latent constructs & Observed variables & $\begin{array}{l}\text { Standardized } \\
\text { regression weights }\end{array}$ & $\begin{array}{l}\text { Squared multiple } \\
\text { correlations }\end{array}$ \\
\hline \multirow[t]{7}{*}{ Perceived significance } & Q1 & 0.688 & 0.474 \\
\hline & Q2 & 0.687 & 0.472 \\
\hline & Q5 & 0.691 & 0.477 \\
\hline & Q6 & 0.728 & 0.530 \\
\hline & Q7 & 0.606 & 0.367 \\
\hline & Q8 & 0.751 & 0.564 \\
\hline & Q9 & 0.859 & 0.738 \\
\hline \multirow[t]{5}{*}{ Course Content } & Q3 & 0.649 & 0.421 \\
\hline & Q4 & 0.679 & 0.461 \\
\hline & Q14 & 0.790 & 0.624 \\
\hline & Q15 & 0.782 & 0.612 \\
\hline & Q16 & 0.804 & 0.646 \\
\hline \multirow[t]{5}{*}{ Student Satisfaction } & Q10 & 0.684 & 0.467 \\
\hline & Q11 & 0.524 & 0.274 \\
\hline & Q12 & 0.607 & 0.368 \\
\hline & Q13 & 0.769 & 0.592 \\
\hline & Q17 & 0.699 & 0.489 \\
\hline
\end{tabular}

The model performance is assessed by examining the ensemble of "goodness-of-fit" statistics which examine the discrepancy between the pattern of variances and covariances implied by the model and the actual pattern of variances and covariances observed in the data (Kline 1998; Santor et al., 2011). Thus, in this study, five goodness-of-fit indices were computed: The chi-square test, the chi-square/df ratio, the incremental fit index (IFI), the comparative-fit index (CFI), and the root mean squared error approximation (RMSEA).

In general, $\chi 2$ d.f. ratios of less than five are deemed as indicating a good fit, with ratios less than two indicating overfitting (Medsker \& Turban, 1994). Kline (1998); Sakri et al. (2012) maintain that a $\chi 2 /$ d.f. ratio of 3 or less is a reasonably good indicator of model fit. In the literature, the IFI and CFI values above 0.9 (Bentler, 1990; Ijaz, 2011), and the RMSEA values below 0.08 indicate good fit (Byrne, 1998; Kline, 1998; Medsker \& Turban, 1994).

In this study, the initial measurement model did not demonstrated recommended levels of goodness of fit $(\chi 2$ $=413.373, \chi 2 /$ d.f. $=3.533$, IFI $=0.827, \mathrm{CFI}=0.825$ and RMSEA $=0.124)$. If the statistical indices of a preliminary model are not acceptable, specification searches are conducted where modification indices (MI) may suggest adding additional paths in the existing model. ${ }^{1}$ The process may continue until a final model indicates acceptable fit statistics (De Carvalho \& Chima, 2014: 9; Min and Mentzer, 2004). Accordingly, in

${ }^{1}$ Only MI values above 10 should be considered for modification in the model (Gürbüz, 2019). 
this study, six additional paths were drawn between e13-e14 (MI value $=52.810)$, e1-e2 $($ MI value $=$ 48.580), e15-e17 (MI value = 17.080), e3-e6 (MI value =14.073), e14-e15 (MI value = 12.305) and e2-e3 $($ MI value $=10.374)$ in six steps until the model shows satisfactory fit statistics.

After the modifications, the $\chi^{2}$ value was 225.613 with 111 degrees of freedom and $\chi 2 /$ d.f. ratio was 2.033 . Other values also indicated good fit in the re-specified measurement model (IFI $=0.933, \mathrm{CFI}=0.932$ and RMSEA $=0.079)$ as indicated in Table

\section{The structural model}

The results suggest that the structural model does have a satisfactory fit $(\chi 2=238.710, \chi 2 /$ d.f. $=1.880, \mathrm{CFI}=$ 0.935 , and IFI $=0.936$, RMSEA $=0.073$ ) as seen in Table 4 . The resulting model is shown in Figure 1.

Table 4. Goodness-of-Fit Indices of Measurement and Structural Models

\begin{tabular}{|l|l|l|l|l|}
\hline Goodness of fit measures & $\begin{array}{l}\text { Measurement } \\
\text { Model }\end{array}$ & $\begin{array}{l}\text { Respecified } \\
\text { measurement model }\end{array}$ & $\begin{array}{l}\text { Structural } \\
\text { Model }\end{array}$ & $\begin{array}{l}\text { Cut-off } \\
\text { Value }\end{array}$ \\
\hline Chi-square $(\chi 2)$ & 413.373 & 225.613 & 238.710 & N/A \\
\hline Degrees of freedom (d.f.) & 117 & 111 & 127 & N/A \\
\hline $\begin{array}{l}\text { Chi-square/degrees of freedom } \\
(\mathrm{x} 2 / \mathrm{df})\end{array}$ & 3.533 & 2.033 & 1.880 & $1.0-5.0$ \\
\hline Comparative Fit Index (CFI) & 0.825 & 0.932 & 0.935 & $>0.90$ \\
\hline $\begin{array}{l}\text { Incremental Fit Index (IFI) } \\
\text { Root Mean Square of } \\
\text { Approximation (RMSEA) }\end{array}$ & 0.124 & 0.933 & 0.936 & $>0.90$ \\
\hline
\end{tabular}

Note: $\mathrm{n}=166$

Figure 1. The Structural Model 


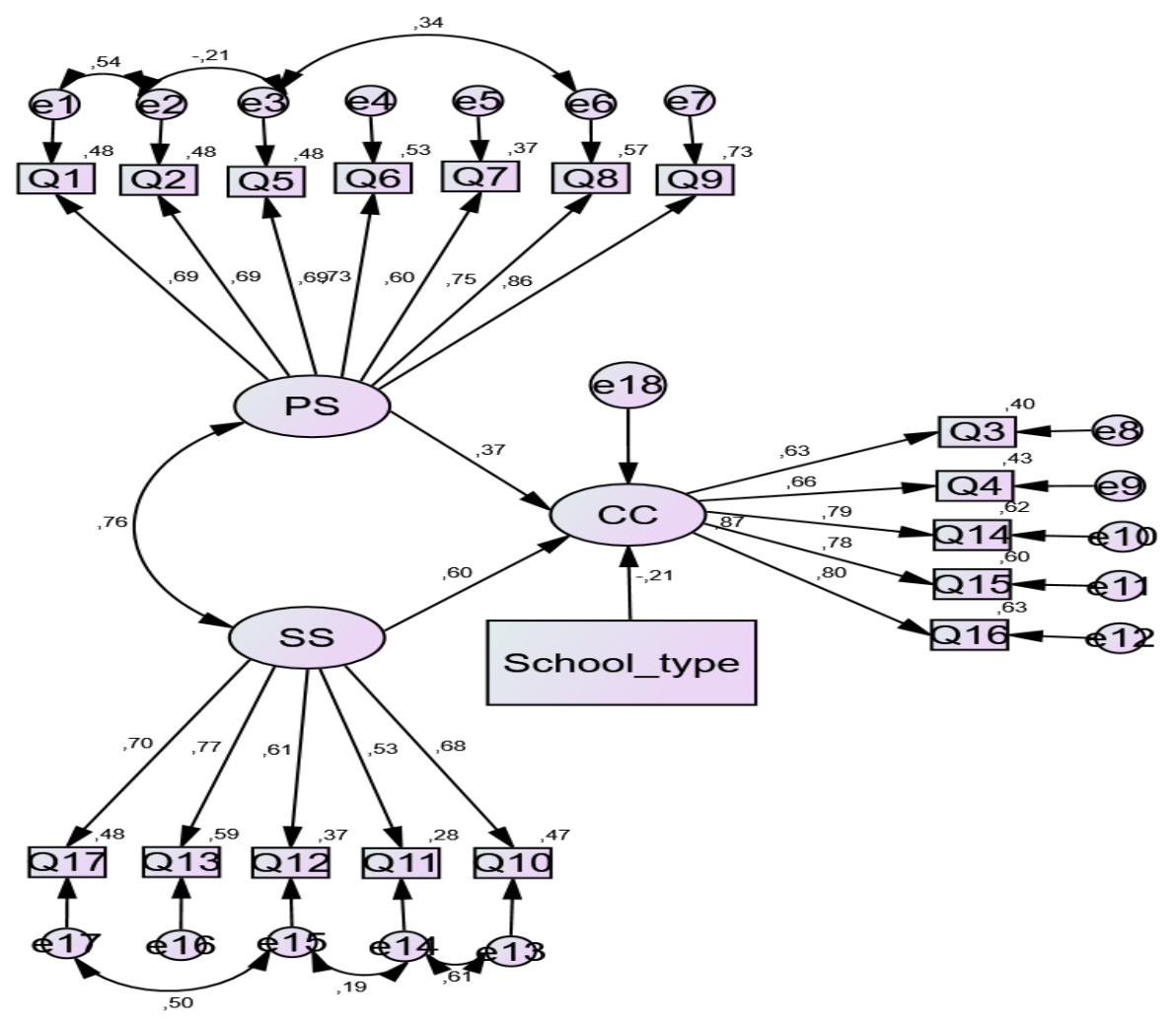

\section{CONCLUSION}

Today, students are generally regarded as customers, and they are not mere resources which are necessary for the higher education institutions. Therefore, their perception, satisfaction and evaluation about offered courses are a major concern for all public administration/affairs departments. In line with this, the current study aimed at exploring the elements affecting public administration students' course content evaluation. Empirical data were collected from 171 public administration students from one foundation and two public universities using the questionnaire method and the relationships were examined through structural equation modeling.

As discussed earlier, one of the strengths of the study is that exploratory factor analysis (EFA) and confirmatory factor analysis (CFA) were both applied to minimize the potential common method variance effect.

In the study, the model proves that the public administration students' evaluation of course content with the courses offered in the department is a complex and multidimensional concept that can best be shown through three main factors, namely student satisfaction, perceived significance and school type. In contrast to the literature, no significant relationship was observed between gender and course content evaluation in the study. Moreover, public administration students' course content approval rate was higher if they were enrolled in a public university.

Finally, the findings of this study offer valuable insight into the significance-content-satisfaction relationship. However, one should bear in mind that the research is limited to public administration students and research methods course. Besides, any difficulties identified should be regarded as opportunities for improvement. Given the importance of course content evaluation underlined in this study, future studies are recommended to explore pedagogical issues such as the impact of students' background and instructors' teaching styles. In addition, as the research participants of the current study were chosen from public administration students, future studies may seek to determine if public administration students have different motivations than other social sciences students. 


\section{REFERENCES}

Alves, H., \& Raposo, M. (2009). The measurement of the construct satisfaction in higher education. The Service Industries Journal, 29(2), 203-218.

Aoki, N. (2015). Institutionalization of New Public Management: The case of Singapore's education system. Public Management Review, 17(2), 165-186.

Arbaugh, J. B. (2000). Virtual classroom characteristics and student satisfaction with internet-based MBA courses. Journal of Management Education, 24(1), 32-54.

Atchley, W., Wingenbach, G. \& Akers, C. (2013). Comparison of course completion and student performance through online and traditional courses. The International Review of Research in Open and Distance Learning, 14(4), 104-116.

Banerjee, M. \& Brinckerhoff, L. C. (2002). Assessing student performance in distance education courses: Implications for testing accommodations for students with learning disabilities. Assessment for Effective Intervention, 27(3), 25-35.

Bentler, P.M. (1990). Comparative fit indexes in structural equation models. Psychological Bulletin, 107, 238-246.

Betoret, F. D. (2007). The influence of students' and teachers' thinking styles on student course satisfaction and on their learning process. Educational Psychology, 27(2), 219-234.

Brans, M. \& Coenen, L. (2016) The Europeanization of Public Administration teaching, Policy and Society, 35:4, 333-349.

Bright, L., \& Graham Jr, C. B. (2016). Predictors of graduate student satisfaction in public administration programs. Journal of Public Affairs Education, 22(1), 17-34.

Byrne, B.M. (1998). Structural Equation Modeling with LISREL, PRELIS and SIMPLIS. NJ: Lawrence Erlbaum Associates.

Buckley, A. (2013). Engagement for enhancement: Report of a UK survey pilot. York: Higher Education Academy.

Chamillard, A. T., \& Merkle, L. D. (2002). Evolution of an introductory computer science course: The long haul. Journal of Computing Sciences in Colleges, 18(1), 144-153.

Chan, A. P., Lam, P. T., Chan, D. W., Cheung, E., \& Ke, Y. (2010). Critical success factors for PPPs in infrastructure developments: Chinese perspective. Journal of Construction Engineering and Management, 136(5), 484-494.

Colorado, J. T. \& Eberle, J. (2010). Student demographics and success in online learning environments. Emporia State Research Studies, 46(1), 4-10.

De Carvalho, J., \& Chima, F. O. (2014). Applications of structural equation modeling in social sciences research. American International Journal of Contemporary Research, 4(1), 6-11.

Durmuş, B., Yurtkoru, E. S., \& Çinko, M. (2013). Sosyal Bilimlerde SPSS İle Veri Analizi. [Data Analysis in Social Sciences with SPSS]. (5 ${ }^{\text {th }}$ edition). İstanbul: Beta Publishing.

Ebdon, C. (1999). Teaching public finance administration online: A case study. Journal of Public Affairs Education, 5(3), 237-246.

Elliot, K. M., \& Healy, M. A. (2001). Key factors influencing student satisfaction related to recruitment and retention. Journal of Marketing for Higher Education, 10, 1-11.

Finnie, R., Mueller, R. E., \& Childs, S. (2010). Family Background, Cultural Capital and Access to Higher Education in Canada. Graduate School of Public and International Affairs. MESA Project (s. 9-12). Germany: XXIV Annual Conference of the European Society for Population Economics. 
Fox, P., \& Skitmore, M. (2007). Factors facilitating construction industry development. Building Research and Information, 35(2), 178-188.

Garg, M. (2018). Student satisfaction as determinant of academic success of distance learners: A study across distance learning courses. The Online Journal of Distance Education and e-Learning, 6(3), 30-43.

George, D., \& Mallery, P. (2016). IBM SPSS Statistics 23 Step by Step: A Simple Guide and Reference. New York, NY: Routledge.

Gürbüz, S. (2019). Amos ile yapısal eşitlik modellemesi. Ankara: Seçkin.

Hair, J. F., Black, W. C., Babin, B. J., \& Anderson, R. E. (2014). In J. F. Hair, Jr., W. C. Black, B. J. Babin, $\&$ R. E. Anderson (Eds.), Multivariate data analysis (Pearson new international seventh ed.). Harlow, Essex: Pearson.

Han, H., Kiatkawsin, K., Kim, W., \& Hong, J. H. (2018). Physical classroom environment and student satisfaction with courses. Assessment \& Evaluation in Higher Education, 43(1), 110-125.

Harris, G., Froman, J., \& Surles, J. (2009). The professional development of graduate mathematics teaching assistants. International Journal of Mathematical Education in Science and Technology, 40(1), 157-172.

Hau-Siu Chow, I. (1995). Management education in Hong Kong: needs and challenges. International Journal of Educational Management, 9(5), 10-15.

Hearn, J. C. (1985). Determinants of college students' overall evaluations of their academic programs. Research in Higher Education, 23(4), 413-437.

Hergüner, B. (2019). Identifying the motives of social sciences students for learning research methods: a Phenomenological study. Kurklareli University Journal of the Faculty of Economics and Administrative Sciences, 8(2), 178-187.

Holtbrügge, D., \& Engelhard, F. (2016). Study Abroad Programs: Individual Motivations, Cultural Intelligence, and the Mediating Role of Cultural Boundary Spanning. Academy of Management Learning \& Education, 15(3), 435-455.

Horvat, A., Krsmanovic, M., \& Djuric, M. (2012). Differences in students' satisfaction with distance learning studies. International Journal of Social, Education, Economics and Management Engineering, 6(6), 1412-1415.

Ijaz, A., Irfan, S. M., Shahbaz, S., Awan, M., \& Sabir, M. (2011). An empirical model of student satisfaction: Case of Pakistani public sector business schools. Journal of quality and Technology Management, 7(2), 91-114.

Irani, T. (1998). Communication potential, information richness and attitude: A study of computer mediated communication in the ALN classroom. ALN magazine, 2(1), 1-12.

Jakobsen, M., \& Jensen, R. (2015). Common method bias in public management studies. International Public Management Journal, 18(1), 3-30.

Keller, J. (1983). Motivational design of instruction. In Reigeluth, C. M. (Ed.), Instructional design theories and models: An overview of their current status (1st ed.). Hillsdale, NJ: Lawrence Erlbaum Associates.

Kline, P. (1994). An Easy Guide to Factor Analysis. London: Routledge.

Kline, R. B. (1998). Principles and Practice of Structural Equation Modeling. New York: The Guilford Press.

Liem, G. A. D. (2019). Academic performance and assessment. Educational Psychology, 39(6), 705-708. DOI: $10.1080 / 01443410.2019 .1625522$

Lopez-Littleton, V. \& Blessett, B. (2015). A Framework for Integrating Cultural Competency into the Curriculum of Public Administration Programs, Journal of Public Affairs Education, 21:4, 557-574, DOI: $10.1080 / 15236803.2015 .12002220$ 
Medsker, L., \& Turban, E. (1994). Integrating expert systems and neural computing for decision support. Expert Systems with Applications, 7(4), 553-562.

Min, S., \& Mentzer, J. T. (2004). Developing and measuring supply chain management concepts. Journal of business logistics, 25(1), 63-99.

Moore, M. G. (1989). Editorial: Three types of interaction, The American Journal of Distance Education. $3(2), 1-6$.

Moore, M. G., \& Kearsley, G. (1996). Distance education: A systems view. New York, NY: Wadsworth.

Nu'man, A. (2012). A Framework for Adopting E-Voting in Jordan. Electronic Journal of e-Government, $10(2), 133-146$.

Özdamar, K. (1999). Paket Programlar Ile İstatistiksel Veri Analizi [Statistical data analysis by custom softwares]. Eskişehir: Kaan Publishing.

Özdemirci, A., Özcan, E. D., \& İldaş, G. (2014). The Relationship between World Views of Rectors with Corporate. International Journal of Business and Management, 9(1), 149-167.

Pallant, J. (2001). SPSS survival manual: A step-by-step guide to data analysis using SPSS for windows. Philadelphia, PA: Open University Press.

Pike, G. R. (1993). The relationship between perceived learning and satisfaction with college: An alternative view. Research in Higher Education, 34(1), 23-40.

Podsakoff, P.M., MacKenzie, S.B., Lee, J.Y. and Podsakoff, N.P. (2003), "Common method biases in behavioral research: a critical review of the literature and recommended remedies", Journal of Applied Psychology, 88(5), 879-903.

Powell, D. C. (2007). Student satisfaction with a distance learning MPA program: A preliminary comparison of on-campus and distance learning students' satisfaction with MPA courses. MERLOT Journal of Online Learning and Teaching, 3 (1), 1-18.

Rissi, J.J. \& Gelmon, S.B. (2014). Development, Implementation, and Assessment of a Competency Model for a Graduate Public Affairs Program in Health Administration, Journal of Public Affairs Education, 20:3, 335-352.

Romiszowski, A. (2004). How's the e-learning baby? Factors leading to success or failure of an educational technology innovation. Educational Technology, 44(1), 5-27.

Rubaii, N. (2019). Why research methods matter: Essential skills for decision-making. Journal of Public Affairs Education, 25:2, 277-279, DOI: 10.1080/15236803.2019.1565253

Sakri, S., Salim, J. \& Sembok, T.M.T. (2012). Information Communications and Technology (ICT) Abuse in the Malaysian Public Sector: The Influence of Ethical, Organisational Bond and General Deterrence Factors. Akademika 82(1), 125-137.

Santor, D. A., Haggerty, J. L., Lévesque, J. F., Burge, F., Beaulieu, M. D., Gass, D., \& Pineault, R. (2011). An overview of confirmatory factor analysis and item response analysis applied to instruments to evaluate primary healthcare. Healthcare Policy, 7(Special Issue), 79 - 92.

Schram, C. M. (1996). A meta-analysis of gender differences in applied statistics achievement. Journal of Educational and Behavioral Statistics, 21(1), 55-70.

Schutt, R. K. (2004). Investing the social world. Thousand Oaks, California: Pine Forge.

Shea, P. J., Pickett, A. M., \& Pelz, W. E. (2003). A follow-up investigation of teaching presence in the SUNY learning network. Journal of Asynchronous Learning Networks, 7(2), 61-80.

Shur, D.D. (2006). Exploratory or Confirmatory Factor Analysis? Statistics and Data Analysis, SUGI 31. Retrieved January 11, from http://tx.liberal.ntu.edu.tw/ PurpleWoo/Literature/!DataAnalysis/FactorAnalysis_SAS.com_200-31.pdf. 
Simpson, C., \& Du, Y. (2004). Effects of learning styles and class participation on students' enjoyment level in distributed learning environments. Journal of Education for Library and Information Science, 123-136.

Swan, K., Shea, P., Fredericksen, E., Pickett, A., Pelz, W., \& Maher, G. (2000). Building knowledge building communities: Consistencies, contact and communication in the virtual classroom. Journal of Educational Computing Research, 23(4), 359-383.

Swan, K. (2001). Virtual interaction: Design factors affecting student satisfaction and perceived learning in asynchronous online courses. Distance Education, 22 (2), 306-316.

Tabachnick, B. G., \& Fidell, L. S. (2007). Using multivariate statistics. Boston: Pearson.

Tallent-Runnels, M. K., Lan, W. Y., Fryer, W., Thomas, J. A., Cooper, S., \& Wang, K. (2005). The relationship between problems with technology and graduate students' evaluations of online teaching. The Internet and higher education, 8(2), 167-174.

Tan, Ş. (2009). KR-20 ve Cronbach Alfa Katsayılarının Yanlış Kullanımları [Misuses of KR-20 and Cronbach's Alpha Reliability Coefficients]. Eğitim ve Bilim, 34(152), 101-112.

Tehseen, S., Ramayah, T., \& Sajilan, S. (2017). Testing and controlling for common method variance: A review of available methods. Journal of Management Sciences, 4(2), 142-168.

Ugaddan, R. G., \& Park, S. M. (2017). Quality of leadership and public service motivation. International Journal of Public Sector Management, 30(3), 270-285.

West, J. (1994). Teaching public personnel management in three types of higher educational institutions. Review of Public Personnel Administration, 14(4), 22-38.

Yaşar, M. (2014). Bilimsel araştırma yöntemleri dersine yönelik tutum ölçeği geliştirme çalışması: Geçerlik ve güvenirlik [Developing an Attitude Scale Related to Scientific Research Methods Course: Validity and Reliability]. Eğitim Bilimleri Araştırma Dergisi, 4(2), 109-129.

Young, A. \& Norgard, C. (2006). Assessing the quality of online courses from the students' perspective. Internet and Higher Education, 9, 107-115. 